\title{
Survey Based Study on Attitude of Student Teachers towards Microteaching.
}

\author{
${ }^{1}$ Mrs. T.N.Rama ${ }^{2}$ Sri. Y. Vasudhakar Reddy \\ ${ }^{I}$ Zoology faculty, A.P. Model School, Andhra Pradesh, India. \\ ${ }^{2}$ Principal, Sri Venkateswara College of Education, Chittoor, Andhra Pradesh, India.
}

\begin{abstract}
The main purpose of this study was to examine the attitude of student teachers towards Microteaching. In this study, Normative Survey Method was adopted. The participants of the study were 150 student teachers of private B.Ed colleges of Chittoor town, Andhra Pradesh, India in 2009-2010 session. The tool used in the study for data collection was a 30-item questionnaire developed by the researchers. An observation schedule module for student teachers was constructed by the researchers. The content validity of tool was established. The reliability of tool was established using test-retest method which was found to be 0.79 $(79 \%)$. Data was analyzed using Descriptive Statistics (Mean and standard deviation), Non-Parametric (ChiSquare test) and differential analysis - " $t$ " test. The findings revealed that the entire sample of student teachers had favourable attitude towards Microteaching and they were of opinion that the Microteaching method provides a scope to evaluate their strengths and weaknesses in teaching. Based on the findings, suggestions were made for improving the teaching skills in student teachers using Microteaching technique so that they can face the real classroom situation with out fear.
\end{abstract}

Keywords: Attitude, Microteaching, Test-retest method, Descriptive, Non-Parametric, Differential Statistics, Microteaching Laboratory, Real Classroom.

\section{Introduction}

Teacher education is an integral component of the educational system. It is intimately connected with society and it is conditioned by the ethos, culture and character of action. Professional training of teachers is key to quality enhancement of school education. There are three main quality concerns in teacher education: (a) inculcation of value system appropriate to the teaching profession; (b) development of competencies for different performance areas; (c) recurrent training to keep pace with new trends in education.

The National Council for Teacher Education (NCTE) was established on $17^{\text {th }}$ August 1995 through an Act of Indian Parliament (No. 73 of 1993) as a statutory body to achieve planned and coordinated development of teacher education system throughout the country, the regulation and proper maintenance of norms and standards in teacher education system and for matters concerned there with.

Teaching skills are a set of interrelated activities a teacher performs in the classroom with a view to facilitate learning in students.

According to Brown (1975) “ Teaching skills are a set of related teaching acts or behaviours performed with the intention to facilitate pupils learning".

Joyce and Weil (1978) defined "Teaching skill is a particular teaching behaviour that contributes to the effectiveness and uniqueness of a teaching model".

In the words of Singh (1979) "Teaching skill is a set of teacher behaviour which are especially effective in bringing about desired changes in pupils".

\section{Microteaching - a modern innovation.}

Teaching practice or student teaching programme is poorly organized, improperly conducted and hopelessly evaluated in most of the colleges and universities. The traditional pattern of such student teaching programme has resulted in producing incompetent and ineffective classroom teachers. This situation has caused to think about some alternative measures and techniques to bring improvement in the student teaching programme. Microteaching is one of such innovation and techniques that has emerged on the map of teacher education for improving the student teaching programme.

Microteaching was conceived and first implemented as a part of teacher education programme at Stanford University in 1963. The term 'Microteaching' was coined by Allen and his associates at Stanford (Allen and Ryan, 1969). The first reference to Microteaching in India goes as back as in 1967 when Tiwari initiated a project on Microteaching in the Central Pedagogical Institute at Allahabad. Allen's Visit to different teacher training institutes in India during 1969-70 also caused a great stir among the Indian teacher educators and the student-teachers as well (D, Lima 1977). G.B.Shah tried an experiment in Microteaching with the help of a tape recorder in faculty of education at Baroda in 1970. NCERT (National Council of Educational Research 
and Training) has conducted a series of research projects and training sessions for teacher educators in all states and Microteaching is a part of B.Ed programme of nearly all the Indian Universities.

Microteaching is an experiment in the field of teacher education. It is a student teacher skill training technique and not a teaching technique. Microteaching involves practicing one skill at a time, reducing the class size to 5-10 pupils, reducing the duration of micro lesson to 5-10 minutes and limiting the content to a single concept. The students are provided immediate feedback in terms of peer group feedback, tape recorded/cctv recorded version etc.

\section{MICROTEACHING CYCLE}

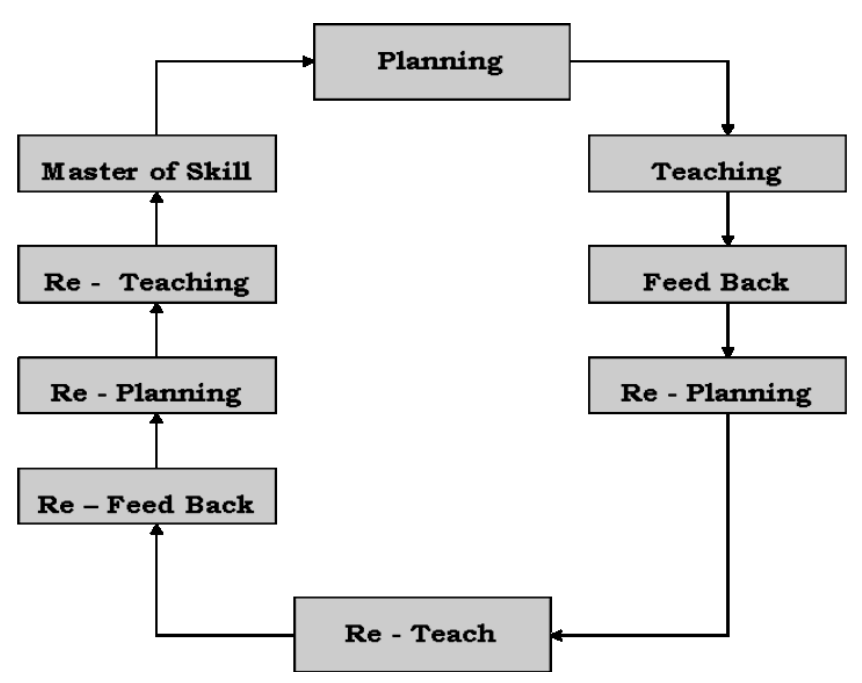

According to J.C.Clift et.al, Microteaching procedure comprises of three phases. (a) Knowledge acquisition phase: Here, student teacher gains through literature survey, observing demonstration lesson - mode of skill presentation. The main component here is modeling. (b) Skill acquisition phase: Here, student teacher plans and prepares a micro lesson and practices the skill. The two components in this phase are microteaching setting and feedback. (c) Transfer phase:Here, student teacher integrates different skills practiced and teaches in a real classroom setting.

Microteaching Application Process

Anantha Krishnan (1993) summarized microteaching process in nine stages:

- Lesson planning : having clear cut objectives, and an appropriate planned sequence.

- Set induction: the process of gaining pupil attention at the beginning of the class.

- Presentation: explaining, narrating, giving appropriate illustrations and examples, planned repetition where necessary.

- Stimulus variation: avoidance of boredom amongst students by gestures, movements, focusing, silence, changing sensory channels etc.

- Proper use of audio-visual aids.

- Reinforcement: recognizing pupil difficulties, listening, encouraging pupil participation and response.

- Questioning: fluency in asking questions, passing questions and adapting questions.

- Silence and nonverbal cues (body language)

- Closure: method of concluding a teaching session so as to bring out the relevance of what has been learnt, its connection with past learning and its application to future learning.

According to Allen, D.W. (1966): Microteaching is a scaled down teaching encounter in class size and class time.

According to Passi, B.K. and Lalitha, M.S.(1976): Microteaching is a training technique, which requires student teachers to teach a single concept using specified teaching skill to a small number of pupils in a short duration of time.

According to Flanders, Ned.A. (1970): Microteaching programme is organized to expose the trainees to an organized curriculum of miniature teaching encounters, moving from the less complex to the more complex. 


\section{Statement Of The Problem And Purpose Of The Study.}

There are two types of managements, controlling Secondary Teacher Training Institution in the state of Andhra Pradesh. One is the IASE under the Universities and other is Colleges of Education under private management bodies. bodies.

There are three colleges of Education in the Chittoor town functioning under private management

What is the status of Microteaching practice in the Colleges of Education? What are the facilities available to conduct Microteaching classes in this type of institution? What is the attitude of student teachers towards Microteaching? It is also required to find out the problems regarding the practice of Microteaching and to suggest corrective measure for the improvement at the Microteaching sessions.

In order to seek the answer to the above research questions, the researchers thought it worthwhile to undertake the present study entitled "Survey based study on attitude of student teachers towards Microteaching".

\section{Methodology}

In this study, Normative Survey Method is adopted. It involves describing, recording, analyzing and interpreting the data which are all directed towards the better understanding of the educational problem and finding solutions for them.

\section{Location of the study}

The research was conducted for the student teachers of private B.Ed colleges of Chittoor town, Andhra Pradesh.

\section{Sample of the study}

In this study, the researchers took a random sample of 150 student teachers of private B.Ed colleges of Chittoor town, Andhra Pradesh.

Table-1 Distribution of the Sample Student Teachers

\begin{tabular}{|c|c|c|c|}
\hline Sl.No & \multicolumn{2}{|c|}{ Categories } & Number \\
\hline 1 & \multicolumn{2}{|c|}{ Entire Sample } & 150 \\
\hline \multirow{2}{*}{2} & \multirow{2}{*}{ Gender } & Male & 75 \\
\hline & & Female & 75 \\
\hline \multirow{2}{*}{3} & \multirow{2}{*}{ Locality } & Rural & 74 \\
\hline & & Urban & 76 \\
\hline \multirow{2}{*}{4} & \multirow{2}{*}{ Age } & Upto 23 years & 110 \\
\hline & & Above 23 years & 40 \\
\hline \multirow{2}{*}{5} & \multirow{2}{*}{ Educational Qualification } & UG & 84 \\
\hline & & PG & 66 \\
\hline \multirow{4}{*}{6} & \multirow{4}{*}{ Subjects taken in Methodology } & Maths & 47 \\
\hline & & Physics & 9 \\
\hline & & Biology & 56 \\
\hline & & social & 38 \\
\hline
\end{tabular}

Fig-1 Distribution of the Sample on the Basis of Sub Samples of Student Teachers.

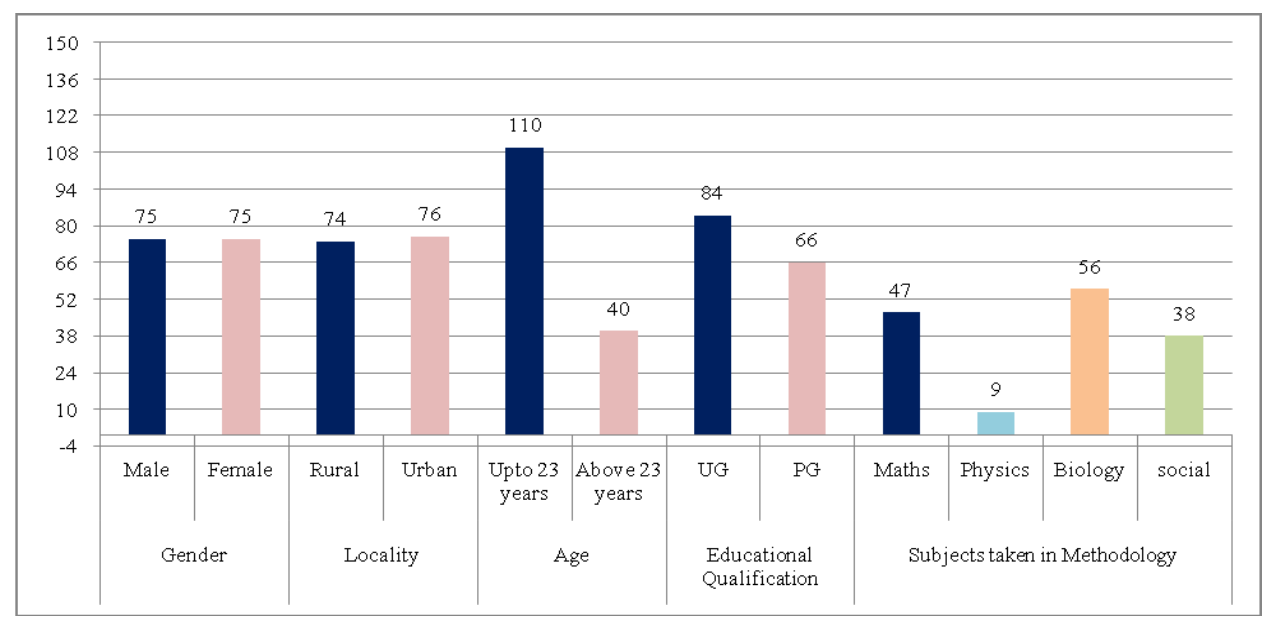


Table 2 Distribution of The Sample Based Upon Their Skill Selected

\begin{tabular}{|c|c|c|c|}
\hline Sl.No & Skill Selected & Frequency & Percent \\
\hline 1 & Introduction & 12 & 8 \\
\hline 2 & Explanation & 30 & 20 \\
\hline 3 & Questioning & 9 & 6 \\
\hline 4 & Probing & 6 & 4 \\
\hline 5 & Illustration & 33 & 22 \\
\hline 6 & Black Board & 27 & 18 \\
\hline 7 & Stimulus Variation & 3 & 2 \\
\hline 8 & Audio - Visual aids & 12 & 8 \\
\hline 9 & Reinforcement & 6 & 4 \\
\hline 10 & Behavior & 6 & 4 \\
\hline 11 & Silence & 3 & 2 \\
\hline 12 & closure & 3 & 2 \\
\hline
\end{tabular}

\section{Tool used for Data collection}

1. Tool for data collection was a 30-item questionnaire developed by the researchers.

The questionnaire included student teacher's personal information, 30 statements regarding Microteaching posed to student teachers to elicit information on the degree of agreement or disagreement.

Out of 30 statements, 15 of them were favourably worded and the remaining 15 were unfavourably worded. The Likert's five point scale was used and the weightings were Strongly

Agree $(\mathrm{SA})=5$, Agree $(\mathrm{A})=4$, Undecided $(\mathrm{U})=3$, Disagree $(\mathrm{D})=2$,

Strongly Disagree $(\mathrm{SD})=1$ for favourable statements and Strongly Agree $(\mathrm{SA})=1$, Agree $(\mathrm{A})=2$, Undecided $(\mathrm{U})=3$, Disagree $(\mathrm{D})=4$, Strongly Disagree $(\mathrm{SD})=5$ for unfavourable statements. An individual's score is the sum of all the scores for the 30 statements.

2. An observation schedule module was constructed by the researchers to record the observation during the Microteaching classes.

\section{Validity of the tool}

The researchers established content validity of the tool. The content validity of the items used in this scale was based on the judgement of both experts and practitioners. In fact, the experts and teachers suggested the various aspects of the Microteaching to be included in this scale.

\section{Reliability of the tool}

Reliability of the tool attitude of student teachers towards Microteaching scale was established by the researchers using test-retest method which was found to be $0.79(79 \%)$.

\section{Method of Data collection}

The researchers distributed the questionnaires to the students with the help of lecturers who supervised students on microteaching. The filled in questionnaires were retrieved on the spot.

\section{Data Analysis}

Descriptive statistics (Mean and Standard deviation) of the attitude scores of the entire sample and its sub-samples were calculated. The null hypothesis for sub-samples was tested by employing (i) ' $t$ " test at 0.05 level of significance and (ii) the chi-square test was employed to find out the attitude of students sub-sample on the basis of subjects taken in methodology.

\section{Results}

The results were presented in line with the research statements and hypotheses. 
Table 3 Showing the frequency distribution attitude towards Microteaching scores for the total sample

\begin{tabular}{|c|c|c|c|c|c|}
\hline Sl.No & C.I & M.P & $\mathrm{F}$ & C.F & C.P.F \\
\hline 1 & $78-82$ & 80 & 4 & 4 & 2.66 \\
\hline 2 & $83-87$ & 85 & 7 & 11 & 7.33 \\
\hline 3 & $88-92$ & 90 & 8 & 19 & 12.66 \\
\hline 4 & $93-97$ & 95 & 13 & 32 & 21.33 \\
\hline 5 & 98-102 & 100 & 19 & 51 & 34 \\
\hline 6 & $103-107$ & 105 & 22 & 73 & 48.66 \\
\hline 7 & $108-112$ & 110 & 22 & 95 & 63.33 \\
\hline 8 & $113-117$ & 115 & 23 & 118 & 78.66 \\
\hline 9 & $118-122$ & 120 & 16 & 134 & 89.33 \\
\hline 10 & $123-127$ & 125 & 10 & 144 & 96 \\
\hline 11 & $128-132$ & 130 & 6 & 150 & 100 \\
\hline
\end{tabular}

From the above table, the calculated mean score for the entire sample was 107.3 and the calculated mean scores of sub-samples ranged from 106.53 to 108.06 which was above the average level. From this, inference was made that the entire sample and all the sub samples had favourable attitude towards Microteaching.

Fig 2 Frequency Polygon for the Distribution of Attitude of Microteaching scores of the total Sample

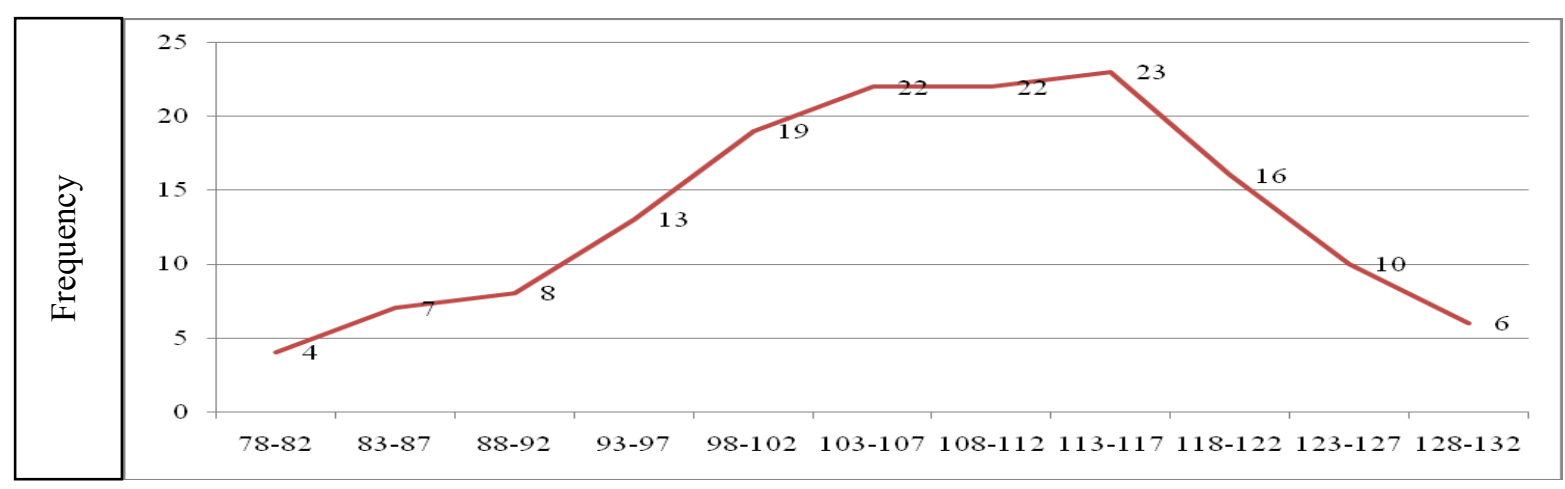

\section{Mid Points}

The table ' $t$ ' value at 0.05 level of significance is 1.96 whereas the calculated ' $t$ ' value for all the subsamples was found to be less than table value. Hence the null hypotheses were accepted. A conclusion was made that sub-samples do not have any significance on attitude of student teachers towards Microteaching.

The chi-square table value is 12.592 to 6 degrees of freedom at 0.05 level. The calculated chi-square value was 4.24 for sub-sample on the basis of subjects taken in methodology. The calculated value was less than table value. So, null hypothesis was accepted. A conclusion was made that there was no significant association between levels of subjects of specialization of B.Ed teacher trainees and their attitude towards Microteaching.

Table - 4 Chi-Square Value for Microteaching Observation of Student Teachers

\begin{tabular}{|c|c|c|c|c|c|c|}
\hline Sl. No & Observed Skills & Samples & $\mathrm{N}$ & Df & $\begin{array}{c}\text { Chi-Square } \\
\text { Value }\end{array}$ & $\begin{array}{c}\text { Significance at } 0.05 \\
\text { level }\end{array}$ \\
\hline \multirow{2}{*}{1} & \multirow{2}{*}{ Class Nature } & Male & 75 & \multirow{2}{*}{1} & \multirow{2}{*}{0.584} & \multirow{2}{*}{ Not Significant } \\
\hline & & Female & 75 & & & \\
\hline \multirow{2}{*}{2} & \multirow{2}{*}{ Class Size } & Male & 75 & \multirow[t]{2}{*}{1} & \multirow{2}{*}{0.166} & \multirow[t]{2}{*}{ Not Significant } \\
\hline & & Female & 75 & & & \\
\hline \multirow{2}{*}{3} & \multirow{2}{*}{ Phase } & Male & 75 & \multirow[t]{2}{*}{1} & \multirow{2}{*}{0.186} & \multirow[t]{2}{*}{ Not Significant } \\
\hline & & Female & 75 & & & \\
\hline \multirow{2}{*}{4} & \multirow{2}{*}{ Lesson Plan } & Male & 75 & \multirow[t]{2}{*}{1} & \multirow{2}{*}{1.119} & \multirow[t]{2}{*}{ Not Significant } \\
\hline & & Female & 75 & & & \\
\hline \multirow{2}{*}{5} & \multirow{2}{*}{ Time } & Male & 75 & \multirow[t]{2}{*}{1} & \multirow{2}{*}{0.490} & \multirow[t]{2}{*}{ Not Significant } \\
\hline & & Female & 75 & & & \\
\hline \multirow{2}{*}{6} & \multirow{2}{*}{ Status } & Male & 75 & \multirow[t]{2}{*}{1} & \multirow{2}{*}{0.433} & \multirow[t]{2}{*}{ Not Significant } \\
\hline & & Female & 75 & & & \\
\hline 7 & Feedback & Male & 75 & 1 & 0.434 & Not Significant \\
\hline
\end{tabular}


Survey Based Study On Attitude Of Student Teachers Towards Microteaching.

\begin{tabular}{|c|c|c|c|c|c|c|}
\hline & & Female & 75 & & & \\
\hline \multirow{2}{*}{8} & \multirow{2}{*}{ Reteaching } & Male & 75 & \multirow[t]{2}{*}{1} & \multirow{2}{*}{0.031} & \multirow[t]{2}{*}{ Not Significant } \\
\hline & & Female & 75 & & & \\
\hline \multirow{2}{*}{9} & \multirow{2}{*}{ Result } & Male & 75 & 1 & \multirow{2}{*}{0} & \multirow[t]{2}{*}{ Not Significant } \\
\hline & & Female & 75 & & & \\
\hline \multirow{2}{*}{10} & \multirow{2}{*}{ Cycle } & Male & 75 & 1 & \multirow{2}{*}{1.555} & \multirow[t]{2}{*}{ Not Significant } \\
\hline & & Female & 75 & & & \\
\hline
\end{tabular}

From the above table it was evident that calculated chi-square values for the Microteaching observation schedule were not significant at 0.05 level. It was inferred that there was no association between gender and their class nature, class size, phase, lesson plan, time taken, status, feedback, reteaching, result and cycle.

\section{Discussion}

From this study and the findings, it was found that the student teachers were having favourable attitude towards Microteaching for entire and all categories of sub-samples.

\section{Suggestions}

Microteaching.

We suggested the following measures to improve the attitude of student teachers towards

1. Microteaching Laboratory should be designed and used properly.

2. Recording facility should be provided.

3. Increasing the time allotted.

4. More demonstration classes from experienced lecturers.

5. Proper guidance from eminent scholars.

6. Instead of peer group, real classroom situation should be provided.

7. The teacher educator should explain the importance of microteaching and should impart knowledge about microteaching.

8. Positive criticism should be done.

9. More skills should be practiced.

10. Content should not be ignored.

\section{Conclusion}

It is generally said that teachers are born and not made. In the modern age, teachers are being produced in teacher education institutions. In modifying student teachers behaviour, Microteaching is an innovative procedure.

\section{References}

[1]. Allen, D.W. and Rayan, K.A., "Microteaching”, Addison Wesley, Reading, mass, 1969.

[2]. Allen, D.W., and Fortune, J.C., "An Analysis of Microteaching: a description, Stanford, Calif. School of Education, Stanford University, Section III, pp.1-11.1967.

[3]. Allen, Dwight, W., "Microteaching: A New Framework for In Service Education". High School Journal 49, 355 -362, 1962.

[4]. Ananthakrishnan N. (1993). Microteaching as a Vehicle of Teacher Training - Its Advantages and Disadvantages. Journal of Postgrad. Medicine. 142-143.

[5]. Bhattacharjee, R., "Effectiveness of Microteaching in developing teaching competence", Extension Service Department, Post Graduate Training College, Shillong, 1981.

[6]. Brown, G.A., "Microteaching: A Programme of Teaching Skills", Methuen and Co.Ltd., London, 1975.

[7]. Das, R.C., Passi, B.K. and Singh, L.C., "Differential Effectiveness of Microteaching Components", Publication Department NCERT, Delhi, March 1980, pp.1-6.

[8]. Dash, B.C., and Basanta Gogoi, Microteaching, Kalyani Publishers, New Delhi, 1998.

[9]. Flanders, N.A., “Analyzing Teaching Behaviour", California, Addison - Wesely Publishing Company, 1970.

[10]. Gandhi, K.A., "Microteaching approach for student teachers", The Progress of Education, Vol.67 (1) (JHGS0718), 1992.

[11]. Garrett H.E., "Statistics in Psychology and Education", Bombay: Vakils, Fefer and Simons Ltd, 1966, p.217.

[12]. Kallenbach, W.W. and Gall, M.D., "Microteaching Versus Conventional Methods in Training Elementary Intern Teachers". Journal of Educational Research, 63, 136-141, 1969.

[13]. Mangal, S.K., Foundations of Educational Technology, Todon Publications, Ludhiana, 2001.

[14]. Passi, B.K. and Lalitha, M.S. "Microteaching in India Context (Mimeo) "Department of Education, Indore University, Indore, 1977.

[15]. Passi, B.K. and Shah, M.M. "Microteaching in Teacher Education". Centre of Advance Study in Education, M.S.University of Baroda, 1974, pp.1-5.

[16]. Report of the Education Commission, 1964-66; Ministry of Education, Government of India, Delhi.

[17]. Report of the Indian Education Commission, 1983; Ministry of Education, Government of India, Delhi

[18]. Report on Teacher Training; Government of India, Committee on Plan Projects, New Delhi. 1964.

[19]. Singh, L.C. and Joshi, A.N. "Microteaching in India, a case study", Publication Department, NCERT, Delhi, October, 1990, pp.1-21.

[20]. Wadhwa B.S., "Factorial structure of attitudes of teacher trainees towards Microteaching", Indian Educational Review, Vol. 23 (4) : $135-43$ (SP 1425), 1988 
Mrs. T.N.Rama M.Sc.,M.Phil., M.Ed. is currently working as Zoology Faculty in A.P. Model School, Government of Andhra Pradesh, India. She pursued B.Ed. and M.Ed. in Sri Venkateswara College of Education, Chittoor, Andhra Pradesh, India. Her Research area is Microteaching.

Sri.Y.Vasudhakar Reddy M.A., M.Phil., M.Ed., Ph.D. is currently working as Principal in Sri Venkateswara College of Education, Chittoor, Andhra Pradesh, India. His Research area is Microteaching. 